\title{
Actions of a regulatory nurse in the management of surgical waiting lists
}

\author{
Atuação do enfermeiro regulador no gerenciamento de listas de espera cirúrgicas \\ Actuación del enfermero regulador en la administración de lista de espera quirúrgicas
}

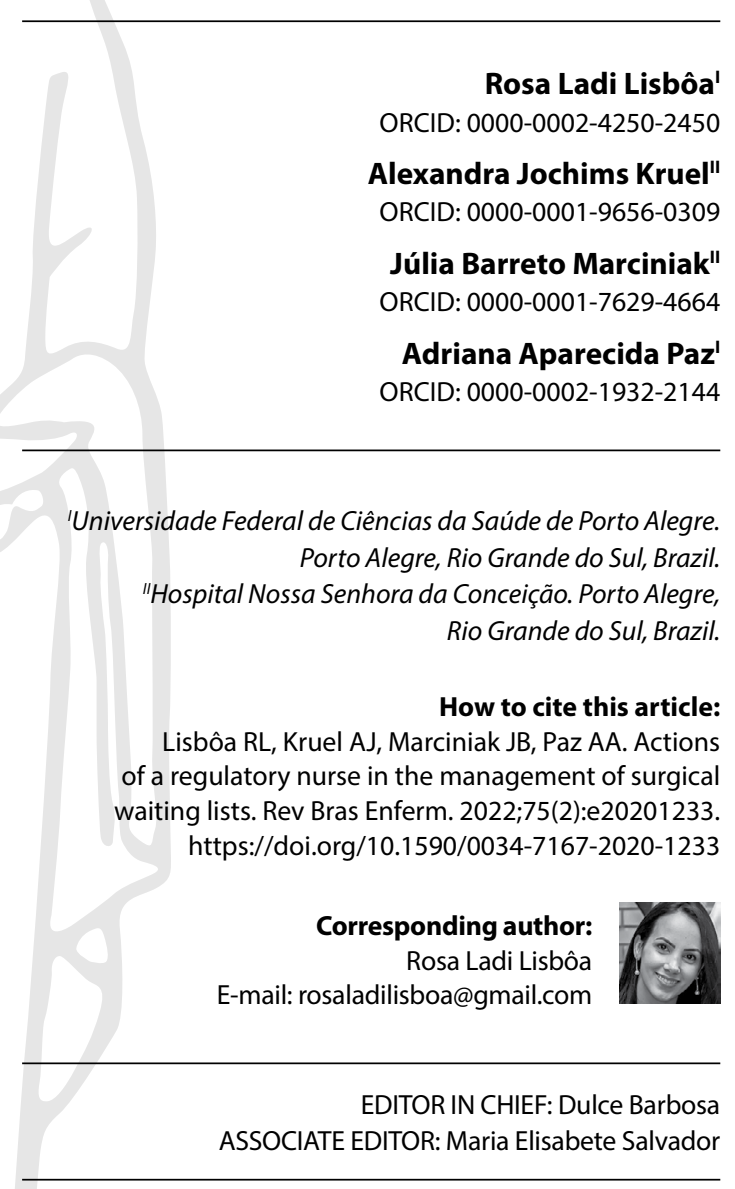

Submission: $12-22-2020$

Approval: 05-09-202

\begin{abstract}
Objectives: to describe the actions of the regulatory nurse in the management of waiting lines for elective surgeries in a public hospital. Methods: this is an experience report about the actions of the regulatory nurse in the management of waiting lines for elective surgeries. Results: the results of this initiative were: diminution in waiting times; elimination of discrepancies that led to access inequality; promotion of safer treatments; actions of the nurse as a manager, conducting and mediating situations between services; autonomy from the high management of the hospital with regard to the manager of waiting lists; and effective communication due to a constant feedback with the medical teams. Final Considerations: the management of the surgical waiting lists must be continuous and systematic, and it must be broader, to include teams that are not involved yet. This initiative can be replicated and improved in other health organizations. Descriptors: Health Services Administration; Waiting Lists; Technology Applied to Waiting Lists; Elective Surgical Procedures; Unified Health System.
\end{abstract}

\section{RESUMO}

Objetivos: descrever a atuação do enfermeiro regulador no gerenciamento das listas de espera para cirurgias eletivas de um hospital público. Métodos: trata-se de um relato de experiência que discorre sobre a atuação do enfermeiro regulador no gerenciamento das listas de espera para cirurgias eletivas. Resultados: os resultados desta iniciativa foram: redução do tempo de espera; eliminação de discrepâncias que promoviam iniquidade de acesso; promoção de maior segurança nos tratamentos; atuação do enfermeiro como gestor para conduzir e mediar situações entre serviços; concessão da autonomia da alta gestão do hospital ao gestor de listas de espera; e comunicação efetiva pelo feedback constante com as equipes médicas. Considerações Finais: o gerenciamento das listas de espera de cirurgias precisa ser contínuo e sistemático, assim como ampliado para as equipes ainda não envolvidas. Essa iniciativa pode ser replicada e aprimorada em outras organizações de saúde. Descritores: Administração de Serviços de Saúde; Listas de Espera; Tecnologia Aplicada a Listas de Espera; Procedimentos Cirúrgicos Eletivos; Sistema Único de Saúde.

\section{RESUMEN}

Objetivos: describir la actuación del enfermero regulador en la administración de listas de espera para cirugías electivas de un hospital público. Métodos: se trata de un relato de experiencia que discurre sobre la actuación del enfermero regulador en la administración de las listas de espera para cirugías electivas. Resultados: como resultados de esta iniciativa, obtuvieron: reducción del tiempo de espera; eliminación de discrepancias que promovían iniquidad de acceso; promoción de mayor seguridad en los tratamientos; actuación del enfermero como gestor para conducir y mediar situaciones entre servicios; concesión de la autonomía de la alta gestión del hospital al gestor de listas de espera; y comunicación efectiva por feedback constante con las equipes médicas. Consideraciones Finales: la administración de las listas de espera de cirugías precisa ser continua y sistemática, así como ampliada para las equipes aún no envueltas. Esa iniciativa puede ser replicada y perfeccionada en otras organizaciones de salud. Descriptores: Administración de los Servicios de Salud; Listas de Espera; Tecnología Aplicada a las Listas de Espera; Procedimientos Quirúrgicos Electivos; Sistema Único de Salud. 


\section{INTRODUCTION}

The management of lists and waiting times for elective surgeries has been reported internationally as a focus of public policies since the mid 1990s, to the point that the Organisation for Economic Co-operation and Development (OECD) treats it as a priority ${ }^{(1)}$. In Brazil, although the subject is an important phenomenon for the health services, its presence in national literature is still scarce ${ }^{(2)}$.

In legal terms, there is also a lack of government prescriptions regarding the management and transparency of waiting lists. However, Federal Bill No. 393/2015, which is currently in the Brazilian congress, states that it should be mandatory to systematically update and publish the waiting lists for elective health care procedures to be carried out in the Single Health System (SUS) ${ }^{(3)}$.

The waiting time for elective treatment, including elective surgeries, is a source of public preoccupation and, therefore, a theme for the creators of policies. The long waiting time has required the allocation of additional public resources in an attempt to diminish the time the patient has to wait for an elective surgical procedure; however, the results from the use of these additional public resources are not clear ${ }^{(4)}$.

Therefore, and according to the literature based on the international practices in universal-access health services, the ideal time between the determination that a surgery is needed and its execution is of 90 days, time frame that can be increased, in exceptional cases, to 180 days $^{(1)}$. In the setting of the experience described in this study, a large part of these lists, which normally have around 2 thousand patients, has waiting times above 180 days, and $40 \%$ of the elective patients have been waiting for more than two years.

Among the shortcomings of the health system, the management of waiting lists for elective surgeries stand out. The focus of this report is a case in 2018 , when a regulatory nurse was designated to manage the waiting lines in the hospital studied here, a public and large-sized general hospital in the South of Brazil. This led to the implementation of improved strategies.

In 2012, the Ministry of Health determined that the hospital studied here should establish an Internal Center of Regulation (NIR), a technical-administrative unit whose responsibilities involve bed management, interfacing with regulatory and access centers, qualifying access flows to hospital services, establishing support mechanisms to reduce waiting time of surgeries, and executing procedures. The nurse's role in the NIR stands out, due to the fact that this professional is capable of performing different functions, contributing to develop the service.

The nurse that works at NIR has the work in the center as their only responsibility, since regulating and managing beds in real time is a demanding and challenging work. It stands out that, in addition to regulating beds, these nurses regulate ambulatory patients, task that involves the external regulation of lines of care for strokes, acute myocardial infarction (AMI), cancer, and post-emergency urolithiasis, as well as auditory rehabilitation and regularization of access.

The nurse at the NIR also has decisive and challenging work in the management of the waiting lists of surgical and clinical patients. In 2019, a manager was admitted at NIR to monitor data, including waiting lists. This partnership helped making the situation of the lists more transparent; one example of this was the identification of patients that underwent surgeries before others who were already in the waiting line for elective operations. This monitoring also made it possible to observe the impact of actions implemented by the nurse in the waiting lists, as well as in the reduction of the list and of the waiting time, thanks to a pre-operative joint effort of list organization with the aid of some medical teams.

In 2017, the manager of the City Health Secretariat (SMS) of the city of the hospital studied adopted measures to promote the transparency of hospital bed use. One of them was the implementation of a software owned by SMS itself, GERINT (system for the management of hospitalizations). Its objective is to monitor the management of hospitalizations in the state using a real-time map of bed occupation. Furthermore, it was determined that the information systems of the hospitals should use the GERINT so their information were updated in real time. It was also determined that elective hospitalizations could only be made and paid when the patients were regulated (that is, formally referred and authorized by SMS).

The institution studied in this research has its own information systems, both managerial and of health care. The health care systems have a specific function targeted at the waiting lists for elective surgical procedures. These data come from the conduct defined for the treatment of the patients as described by assistant physicians.

Initially, the medical teams recorded all information in their waiting lists in many different forms (electronic spreadsheets, text editors, physical notebooks, or pieces of paper). With the advent of the specific information system, some teams started to use it in addition to the physical lists.

In addition, there was no system to follow the progress of the lists, neither in management nor in direct care, with the teams of specialists. This led to several problems involving the disorganization of the lists, such as: duplicate or incongruent information; unregulated patients in waiting lines; long waiting times for certain specialties and procedures; and the absence of mechanisms to prioritize patients. Therefore, there was no knowledge about the concrete reality of the lists (size and waiting time), and it was not possible to manage them.

To optimize the process of improvement of the quality of care to the patient and to be in accordance with the SMS demands, it was necessary to organize the waiting list. That would lead to a diminution in the waiting time for procedures, avoiding potential health complications that could be provoked by delays.

Legally, the hospital must act in accordance with the regulations of the Organic Law of Health ${ }^{(5)}$ and with all health policies in effect. In addition to the legal aspect, many situations gave support to the need for interventions in the management of waiting lists, such as: 1) people claiming for the execution of their surgeries; 2) difficulties identifying the clinical priorities that justify the anticipation of surgeries of patients who "cut in line", including those with judicial orders, without clinical justification; 3) long waiting times, often above the prescribed for the beginning of cancer treatments ${ }^{(6)}$.

Therefore, this intervention was due to the need for complying with legal norms, especially in the search for an effective 
attention to elective surgery patients. Since this is a new field of nursing work, the literature about it is scarce.

\section{OBJECTIVES}

To describe the actions of the regulatory nurse in the management of waiting lines for elective surgeries in a public hospital.

\section{METHODS}

This is an experience report about the actions of a regulatory nurse, who, in the work process, proposed intervention strategies used in the management of waiting lists for elective surgeries. This text describes the actions implemented and their efficacy regarding this management.

The experience report - a tool of descriptive researches based on the reflection about an action or set of actions - addresses a situation experienced during the performance of the work, which is of the interest for the scientific community ${ }^{(7)}$. Therefore, it was the adequate methodology to discuss the experience in the management of waiting lists of a public hospital in the South of Brazil, from 2018 to 2020.

The coordination of the NIR signed the Agreement Term declaring they were aware of the secondary data collection carried out by this study, resulting from the databases of internal management reports. This data is not related to researches with human beings, thus, Research Ethics Committee assessments were not necessary. This initiative did not require direct financial investment, but it used resources from the institution to reorganize the responsibilities and processes of NIR.

\section{PRESENTATION OF THE STRATEGIES USED}

The waiting lists of the hospital come from 20 clinical and surgical specialities, including: center for the care of the obese class III, cardiac surgery, digestive tract surgery, general surgery, plastic surgery, thoracic surgery, vascular surgery, pain and palliative care, endocrinology, gastroenterology, gynecology, mastology, internal medicine, neurology, ophthalmology, cancer surgery, pneumology, proctology, and urology.

It stands out that, during the period where the actions described here were carried out in the institution, the surgical ward was made up by 14 operating rooms. 2 of them were for urgency and emergency procedures, 4 were for small procedures with local anesthesia, and 8 for elective surgeries. However, changes in the organizational structure of the physical area of the ward were necessary due to the COVID-19 pandemic. As a result, from the 14 rooms, 3 became recovery rooms, since the previous recovery room was transformed into an intensive care unit room. Furthermore, there are still 2 urgency and emergency rooms, 2 rooms for patients suspected or confirmed to have COVID-19, and 8 for elective surgeries. During the pandemic, the ward was closed in several moments, and was only used for urgent cases and cancer cases.

During March 2018, only the cardiac, thoracic, and urological surgical teams had their waiting lists completely registered in the information system of the hospital. At the time, many cardiac surgeries were suspended due to the lack of intensive care unit (ICU) rooms, and the longest waiting list was that for urological surgeries.

Considering this reality, there was an attempt to raise the awareness of the medical teams during monthly meetings, which counted on the presence of both the medical teams and the regulatory nurse, responsible for the waiting lists at NIR. Sometimes, the nurse that coordinated the NIR participated, and, from 2019 on, the manager of the hospital also started to participate. In these meetings, the importance of the organization and standardization of waiting lists was explained.

For the standardization to take place, the procedures needed to be organized within the lists of the medical specialities according to a priority classification of the surgeries, considering the severity of cases and the coding of the procedures. Urology can be used as an example of this categorization: Code 1 indicated the patients with oncological diseases; Code 2 referred those who would undergo large procedures (e.g. ureterolitotomy); Code 3, to small procedures (e.g. varicocele, hydrocele); Code 4 indicated urinary incontinence; and Code 5, biopsies.

Then, the regulatory nurse carried out the administrative revision of the waiting lists. This process included a manual verification of the lists. The data of each patient was evaluated in the electronic history of the patient. Furthermore, the patient or a relative was contacted via telephone to identify those whose surgery was not scheduled in the medical history, who did not receive follow up in the adequate speciality in the ambulatory, and who were no longer recommended to have the surgery, but were still on the list. This led to the removal of patients from the waiting list, as well as those who had undergone the procedure in other institution, who passed away, and those who did not accept, after three attempts, to be hospitalized or have the surgery. The information above was provided to the medical teams, and it was demonstrated that patients who had been in the list for longer should have their surgery done faster.

It stands out that the waiting list of this hospital is accessible via an electronic system to all professionals working in the institution. As previously mentioned, these waiting lists have an interface with the GERINT, that is, elective patients automatically appear in the platform.

The regulatory nurse from the NIR was responsible for organizing weekly elective calls of patients to be hospitalized, as well as for organizing groups to jointly carry out pre-operative ambulatory evaluations (medical consultations and all necessary exams). These actions helped to diminish the hospitalization time of the patients who arrived at the hospital on the day of surgery, that is, they did not need to be hospitalized earlier to undergo pre-operative exams. Furthermore, the NIR started to monitor waiting lists monthly and systematically, to raise the awareness of the medical teams, improve communication with them, and evaluate the progress of the results of this initiative.

\section{RESULTS AND DISCUSSIONS}

The effectiveness of these actions was measured by the number of patients in the list and the waiting times to carry out the procedures. This first indicator cannot be analyzed in isolation, due to the dynamic nature of the list. This is why it is necessary to also analyze the waiting times. 
The most relevant results were those of the cardiac and urological teams, whose monitoring, from March 2018 (start of the initiative) and March 2020, produced data that can be seen in Chart 1. The choice of March 2020 as the date for the end of the period monitored is due to the COVID-19 pandemic, since this was when, to avoid collapsing, the hospital suspended elective ambulatory and surgical attention so it could implant measures to confront the crises.

It stands out that the case of urology became a reference case for the other medical teams. Despite the dynamic flow of the list, all codes showed a reduction, both in the number of patients and in the waiting time. From this experience on, other teams were aggregated. This included vascular surgery and otolaryngology, for example (Chart 2).

Chart 1 - Comparative productivity data and results for cardiac and urological surgeries

\begin{tabular}{|c|c|c|}
\hline Specialty & Initial state (March 2018) & $\begin{array}{l}\text { Current state } \\
\text { (March 2020) }\end{array}$ \\
\hline \multirow{3}{*}{ Cardiac surgery } & $\begin{array}{l}159 \text { patients, waiting time of } \\
\text { up to } 4 \text { years }\end{array}$ & $\begin{array}{l}18 \text { patients, } \\
\text { waiting time of } \\
\text { up to } 20 \text { months }\end{array}$ \\
\hline & $\begin{array}{l}46 \text { Code } 1 \text { patients (cancer), } \\
\text { waiting time of up to } 2 \text { years } \\
\text { and } 3 \text { months }\end{array}$ & $\begin{array}{l}5 \text { Code } 1 \\
\text { patients, waiting } \\
\text { time of up to } 3 \\
\text { months }\end{array}$ \\
\hline & $\begin{array}{l}\text { Mean productivity: } 31.3 \\
\text { elective surgeries/month }\end{array}$ & $\begin{array}{l}\text { Mean } \\
\text { productivity: } \\
25.7 \text { elective } \\
\text { surgeries/month }\end{array}$ \\
\hline \multirow{4}{*}{ Urology } & $\begin{array}{l}579 \text { patients, waiting time of } \\
\text { up to } 8 \text { years. }\end{array}$ & $\begin{array}{l}244 \text { patients, } \\
\text { waiting time of } \\
\text { up to } 20 \text { months }\end{array}$ \\
\hline & $\begin{array}{l}72 \text { Code } 1 \text { patients (cancer), } \\
\text { waiting time of up to } 9 \\
\text { months }\end{array}$ & $\begin{array}{l}20 \text { Code } 1 \\
\text { patients, waiting } \\
\text { time of up to } 2 \\
\text { months }\end{array}$ \\
\hline & $\begin{array}{l}\text { Mean hospitalization time: } \\
10.2 \text { days }\end{array}$ & $\begin{array}{l}\text { Mean } \\
\text { hospitalization } \\
\text { time: } 5.2 \text { days }\end{array}$ \\
\hline & $\begin{array}{l}\text { Mean productivity: } 231 \\
\text { elective surgeries/month }\end{array}$ & $\begin{array}{l}\text { Mean } \\
\text { productivity: } \\
205.7 \text { elective } \\
\text { surgeries/month }\end{array}$ \\
\hline
\end{tabular}

The waiting list recorded in the information system of the hospital showed to be an important management tool to guarantee the rights of the patient and provide knowledge to the medical team with regard to the demand for elective surgeries. For this initiative to yield positive results, four aspects must be respected:

- there must be a manager for the process, that is, someone in charge of it, who will bring it forth and act as a mediator between services. In the setting of this report, this process is a responsibility of the NIR; a nurse was selected to be the manager of NIR and a manager of the institution was selected to monitor results;

- the high management of the hospital must give support to the initiative by allowing NIR and the manager of the process to operate autonomously, since this is something that will take teams out of their comfort zones, standardize their actions, and, therefore, take power away from some professionals, which can generate resistance;

- the health needs of the patient are the main objective of this initiative, in accordance with the adoption of the principles of the SUS, especially equity;

- there must be guaranteed constant feedback to medical teams, with consistent information about their performance and progress, the situations to be resolved, and the establishment of new goals and mutual responsibility.

Chart 2 - Comparative productivity data and results for vascular and otolaryngology surgeries

\begin{tabular}{|c|c|c|}
\hline Specialty & Initial state & $\begin{array}{l}\text { Current state } \\
\text { (March 2020) }\end{array}$ \\
\hline \multirow{3}{*}{$\begin{array}{l}\text { Vascular surgery } \\
\quad \text { (started in } \\
\text { September 2019) }\end{array}$} & $\begin{array}{l}56 \text { patients, waiting time of } \\
\text { up to } 6 \text { years and } 11 \text { months }\end{array}$ & $\begin{array}{l}25 \text { patients, } \\
\text { waiting time of up } \\
\text { to } 13 \text { months }\end{array}$ \\
\hline & $\begin{array}{l}\text { Mean productivity: } 102.3 \\
\text { elective surgeries/month }\end{array}$ & $\begin{array}{l}\text { Mean } \\
\text { productivity: } 75.3 \\
\text { elective surgeries/ } \\
\text { month }\end{array}$ \\
\hline & $\begin{array}{l}\text { Mean hospitalization time: } \\
8.1 \text { days }\end{array}$ & $\begin{array}{l}\text { Mean } \\
\text { hospitalization } \\
\text { time: } 6 \text { days }\end{array}$ \\
\hline \multirow{3}{*}{$\begin{array}{l}\text { Otolaryngology } \\
\text { (started in July } \\
\text { 2019) }\end{array}$} & $\begin{array}{l}116 \text { patients, waiting time of } \\
\text { up to } 3 \text { years and } 7 \text { months }\end{array}$ & $\begin{array}{l}124 \text { patients, } \\
\text { waiting time of up } \\
\text { to } 2 \text { years and } 2 \\
\text { months }\end{array}$ \\
\hline & $\begin{array}{l}5 \text { Code } 1 \text { patients (cancer), } \\
\text { waiting time of up to } 10 \\
\text { months }\end{array}$ & $\begin{array}{l}\text { No Code } 1 \text { patient } \\
\text { (cancer) waiting } \\
\text { since December } \\
2019 .\end{array}$ \\
\hline & $\begin{array}{l}\text { Mean productivity: } 26.6 \\
\text { elective surgeries/month }\end{array}$ & $\begin{array}{l}\text { Mean } \\
\text { productivity: } 16.4 \\
\text { elective surgeries/ } \\
\text { month }\end{array}$ \\
\hline
\end{tabular}

This investigation showed was a significant diminution in the waiting time to carry out the elective surgical procedures of the specialties addressed. The waiting can lead to a worsening/ deterioration of the patients' health conditions, to an increased time suffering, to the loss of utility, and even to the death of the patient ${ }^{(1)}$.

The feedback from the medical teams about the actions proposed by the NIR - such as the coding of procedures, consultancies, and the automatic insertion of $\mathrm{AlH}$ in the waiting list - significantly contributed for the development of the medical services, although, at first, the actions demanded readaptations of the work carried out by the teams. It is important to highlight that it was important, for the success of these actions, to count on the involvement of the teams of care and others, such as the diagnostic teams, who determined the priority of the scheduling of exams for pre-operative evaluations in specific ambulatories; the surgical center, which optimized the occupation of surgical rooms; and the ambulatory of specialties. 
This multiprofessional integration led to an improvement in the attention to the patient and was made concrete through effective communication, which was possible due to the joint efforts to keep the relationships and a good relationship with the medical teams and other services. E-mails and instant messaging applications, such as WhatsApp, was also adopted, making dialogs and decision-making faster. The intervention in the waiting lines, in turn, must be carried out based on the principle of equity (one of the doctrinal bases of SUS), meaning that each specific problem should be treated according to its necessity ${ }^{(8)}$.

It stands out, however, that the subjective aspects found in the medical teams are directly reflected on the results of the work. The cardiac and urological surgery teams had good leadership in their team coordinator, and, as was true for the other members in the process, were adequately engaged. This made it possible for the work to be more fluid and effective. These subjective aspects were not true for some of the medical teams addressed, that is, they are not as committed nor as collaborative in their practice. Therefore, the results were not as efficient.

The strategies presented in this study were important and decisive to reach its results. However, for an effective and quality attention to be possible to elective patients, it is necessary for new strategies to be created and for the ones narrated in this study to be effectively implemented for the teams who did not adhere well to the improvement ideas proposed by the NIR.

It should be considered that, one of the measures during the COVID-19 pandemic was the restriction of surgeries, meaning that the demand for elective surgeries was even more suppressed. This is not only the reality of this specific hospital, since the pandemic interrupted most elective surgeries to attend the sudden and expressive increase in the number of patients needing urgent care in intensive care units ${ }^{(9)}$. The contribution, collaboration, and strategical leadership for the implementation and management of surgical waiting lists for surgeries to be carried out after the pandemic will be essential, since this situation significantly affected the health and life of the elective surgery patients ${ }^{(10)}$.

\section{Study limitations}

One of the limitations of this study is in the presentation of the results, which showed only the four medical specialties which were the most engaged in the proposals of intervention, that is, results from the other specialties were not presented. Furthermore, the data presented was not submitted to statistical analysis to verify whether the change was significant $(p<0.05)$.

\section{Contributions for the field of nursing and health}

The implications of this experience report contribute for the practice of the nurse, who is the mediator of the process of regulating the surgical waiting lists, thus strengthening the analysis of indicators and the formulation of strategies for managerial decision making. It stands out that the literature on the management of waiting lists is still incipient in Brazil. Therefore, this report contributes to reiterate the need to create more studies about this theme.

It stands out that the actions of nurses as regulators must be presented, explored, and discussed in their university training, thus improving the competences they develop. As a result, the importance of waiting lists and of NIR in health institutions will be more widely known. Similarly, this theme encourages the offering of professional courses for the improvement of nurses that have this new position opened, and for nurses from other sectors to get to know the attributions, strategies, and actions for bed regulation.

\section{FINAL CONSIDERATIONS}

Considering the scarce literature and legislation on the theme, the NIR had to develop its own model for the management of waiting lists and the execution of actions related to it, including aspects such as raising awareness of its necessity and guaranteeing the commitment of collaborators and teams, changes in processes, and the improvement of information systems, not to mention ways to monitor and evaluate performance. It was also necessary to avoid conflict between the model elaborated by the NIR and the management model of the institution.

The actions presented have been applied to other specialties, considering their specificities. Thus, this study proposes that this initiative can be replicated and improved in all health institutions with waiting lists for elective patients. As it could be observed, the actions mentioned are simple, but constitute a detailed and demanding process, which depended on the involvement of many workers from several sectors of the institution.

The nurse who manages the NIR and was responsible for the management of waiting lists for elective surgeries, was able to establish partnership with medical teams and to create strategies to reduce the number of patients on the waiting list and the waiting time for elective surgeries, thus improving the management of the flow of patients in the beds of the institution. Therefore, the importance of the nurse has been demonstrated, since, as they assume this role in the management of the health services, they provide indirect care, contributing for the quality of the assistance provided to the user.

\section{REFERENCES}

1. Siciliani L, Hurst J. Tackling excessive waiting times for elective surgery: a comparative analysis of policies in $12 \mathrm{OECD}$ countries. Health Policy [Internet]. 2005 [cited 2020 Sep 12];72(2):201-15. Available from: https://www.sciencedirect.com/science/article/pii/S0168851004001617?via\%3Dihub

2. Lippi MC. Gestão de lista de espera como abordagem para planejamento e coordenação de serviços de saúde eletivos. Rev Eletrôn Gestão Saúde [Internet]. 2018 [cited 2020 Sep 12];9(6):159-77. Available from: https://www.mastereditora.com.br/periodico/20200408_122550.pdf

3. Aguiar LOF, Lira ACO. Transparência no Sistema Único de Saúde: iniciativas e desafios na divulgação eletrônica das listas de espera. Cad Ibero-Am Dir Sanit [Internet]. 2018 [cited 2020 Sep 12];7(2):111-24. Available from: https://www.researchgate.net/ publication/326087760_Transparencia_no_Sistema_Unico_de_Saude_-_inciativas_e_desafios_na_divulgacao_eletronica_das_listas_de_espera 
4. Lungu DA, Grillo RT, Nuti S. Decision making tools for managing waiting times and treatment rates in elective surgery. BMC Health Serv Res. 2019;19(1):361-9. https://doi.org/10.1186/s12913-019-4199-6

5. Ministério da Saúde (BR). Lei n 8.080, de 19 de setembro de 1990. Dispõe sobre as condições para a promoção, proteção e recuperação da saúde, a organização e o funcionamento dos serviços correspondentes e dá outras providências [Internet]. Brasília: Ministério da Saúde; 1990 [cited 2020 Sep 12]. Available from: http://www.planalto.gov.br/ccivil_03/leis/L8080.htm

6. Ministério da Saúde (BR). Lei no 12.732, de 22 de novembro de 2012. Dispõe sobre o primeiro tratamento de paciente com neoplasia maligna comprovada e estabelece prazo para seu início [Internet]. Brasília: Ministério da Saúde; 2012[cited 2020 Sep 12]. Available from: http://www.planalto. gov.br/CCIVIL_03/_Ato2011-2014/2012/Lei/L12732.htm

7. Marini ZM, Arrieira I, Jacotec C. Relato de experiência da equipe odontológica em atenção domiciliar em um hospital-escola na cidade de Pelotas, RS, Brasil. RFO UPF. 2017;22(2):158-61. https://doi.org/10.5335/rfo.v22i2.6747

8. Senna SBB. Gestão da fila de espera para cirurgias eletivas em hospitais do Sistema Único de Saúde. Braz. J Surg Clin Res[Internet]. 2020 [cited 2020 Sep 12];30(2):79-82. Available from: https://www.mastereditora.com.br/periodico/20200408_122550.pdf

9. Clarke J, Murray A, Markar SR, Barahona M, Kinross J. New geographic model of care to manage the post-COVID-19 elective surgery aftershock in England: a retrospective observational study. Rev BNJ Open. 2020;10(10):1-9. https://doi.org/10.1136/bmjopen-2020-042392

10. Wiseman SM, Crump RT, Sutherland JM. Surgical wait list management in Canada during a pandemic: many challenges ahead. Can J Surg. 2020;63(3):226-8. https://doi.org/10.1503/cjs.006620 